Int. J. Dev. Biol. 58: 95-106 (2014)

doi: $10.1387 / \mathrm{ijdb} .140069 \mathrm{mw}$

\title{
Progesterone receptor signaling in the initiation of pregnancy and preservation of a healthy uterus
}

\author{
MARGEAUX WETENDORF ${ }^{1,2}$ and FRANCESCO J. DEMAYO*,2,1 \\ ${ }^{1}$ Integrative Molecular and Biomedical Sciences Graduate Program and ${ }^{2}$ Department of Molecular and Cellular \\ Biology, Baylor College of Medicine, One Baylor Plaza, Houston, TX, USA
}

\begin{abstract}
Infertility and reproductive-associated disease are global problems in the world today affecting millions of women. A successful pregnancy requires a healthy uterus ready to receive and support an implanting embryo. As an endocrine organ, the uterus is dependent on the secretions of the ovarian hormones estrogen and progesterone which signal via their cognate receptors, the estrogen and progesterone receptors. The progesterone receptor not only functions using classical nuclear receptor signaling, but also participates in non-genomic signaling at the cellular membrane. The complexity of progesterone signaling is further enhanced by the existence of multiple isoforms and post-translational regulation via kinases and transcription coregulators. This dynamic means of regulation of the progesterone receptor is evidenced in its necessary role in a successful pregnancy. Within early pregnancy, the progesterone receptor elicits activation of its target genes in a spatiotemporal manner in order to allow for successful embryo attachment and uterine decidualization. Additionally, appropriate progesterone signaling is important for the prevention of uterine disease such as endometrial cancer, endometriosis, and leiomyoma. The utilization of progesterone receptor modulators in the treatment of these devastating uterine diseases is promising. This review presents a general overview of progesterone receptor structure, function, and regulation and highlights its important role in the establishment of pregnancy and as a therapeutic target in uterine disease.
\end{abstract}

KEY WORDS: progesterone signaling, progesterone receptor, early pregnancy, mouse model

\section{Introduction}

According to the National Survey of Family Growth, 6.7 million women in the United States are unable to become pregnant or carry a pregnancy to term (Stephen and Chandra, 2000). This inability to reproduce affects the survival of the human species and can disturb the overall well-being of an individual. Furthermore, women are plagued by devastating reproductive tract-associated diseases such as endometrial cancer, endometriosis, and uterine fibroids. Today, there is a limited understanding of uterine disease, including how it originates and the importance of hormone signaling in the persistence of the disease. The increased understanding of these diseases, including the molecular mechanisms that initiate and perpetuate these disease states, is important for the development of new therapeutic treatments.

The uterus is a hormone sensitive organ that responds to the presence of the female ovarian hormones, estrogen and progesterone. Estrogen and progesterone individually bind to their cognate receptors, the estrogen receptor (ESR1) and the progesterone receptor (PGR). These receptors work in concert to establish and maintain pregnancy. Specifically, progesterone signaling is absolutely necessary for a successful pregnancy, conveyed in its namesake, the "pro-gestation" hormone. The in vivo ablation of progesterone signaling results in the inability to establish pregnancy (Lydon et al., 1995). Progesterone signaling involves the binding of progesterone hormone to the PGR, to promote the transcription of target genes (as reviewed in (Mulac-Jericevic and Conneely, 2004)). As a nuclear receptor, the PGR binds hormone and enters into the nucleus to bind DNA to initiate downstream functions within the cell. However, the PGR is also able to successfully promote cellular responses independent of nuclear entrance and DNA binding (Gellersen et al., 2009). This review will provide a broad overview of the structure and function of the PGR including a description of the different PGR isoforms generated as they are conserved between mouse and human. The PGR isoforms display unique functional abilities due to the presence of multiple

Abbreviations used in thispaper: ESR 1, estrogen receptor 1; PGR, progesterone receptor. *Address correspondence to: Francesco J. DeMayo. Department of Molecular and Cellular Biology, Baylor College of Medicine, One Baylor Plaza, Houston, TX,
77030, USA. Tel: 713-798-6241. Fax: 713-790-1275. E-mail: fdemayo @ bcm.edu

Final, author-corrected PDF published online: 8 July 2014.

ISSN: Online 1696-3547, Print 0214-6282 
activation domains. The activation domains are responsible for the ability of the PGR to bind ligand and DNA and the unique ability to recruit other molecules to modulate transcription efficiency. Additionally, the PGR is regulated by a variety of factors including interior protein domains, cytosolic chaperone proteins, post-translational modifications, and the presence or absence of ligand. Upon understanding the structure and function of the PGR and how it is regulated, this review will provide a snapshot of the target genes the PGR regulates within early implantation and uterine stromal cell decidualization.

Progesterone signaling is a highly regulated cellular pathway due to its critical role in the initiation and maintenance of pregnancy (reviewed in (Wang and Dey, 2006)). Upon fertilization of the embryo, the murine embryo travels down the oviduct and implants into the uterine epithelium. The surrounding uterine stroma then undergoes what is known as decidualization in which stromal cells proliferate and differentiate into decidual cells to promote the growth of the embryo (reviewed in (Cha et al., 2012)). The current knowledge regarding progesterone signaling during implantation has been successfully attained via the generation of genetically engineered murine models. These models have provided a wealth of knowledge that was impossible to obtain using human endometrial cell culture in vitro. Utilizing murine ablation techniques, genes critical for pregnancy, many of which are progesterone target genes, have successfully been identified.

Finally, this review will briefly describe the role of progesterone signaling in uterine disease. Although much knowledge has been gained concerning the nature of uterine disease, there are many unknowns regarding how uterine disease initiates and how it can be prevented or effectively treated. Furthermore, synthetic hormones and hormone receptor modulators have been utilized as treatment therapy for these diseases, yet additional studies of their clinical effectiveness is required. Through the increased understanding of how progesterone functions, we can better understand the involvement of progesterone in the initiation, progression, and treatment of these devastating reproductive tract diseases. Additionally, through the utilization of ligands that promote or abrogate progesterone signaling, we can identify new treatment options for women suffering from reproductive disease.

\section{The progesterone receptor: structure, function and regulation}

\section{The progesterone receptor as a nuclear receptor}

The PGR is a member of the nuclear receptor family, characterized by its unique ability to bind ligand within the cytoplasm, dimerize, and enter into the nucleus to bind DNA resulting in the activation of target genes (reviewed in (Mulac-Jericevic and Conneely, 2004)). Nuclear receptors are able to function appropriately as they harbor conserved protein activation domains, known as AF-1 and AF-2 (Meyer et al., 1990). AF-1 is located in the amino terminus of the protein and is responsible for functions independent of ligand binding (reviewed in (Brosens et al., 2004, Ellmann et al., 2009)). Between the AF-1 and AF-2 domain reside the hinge region and a conserved DNA binding domain (Kumar and Chambon, 1988). This binding domain allows for the nuclear receptor to bind to DNA as a dimer and subsequently recruit transcription machinery to begin transcription of the target gene. The DNA binding domain specifically recognizes a particular DNA sequence or motif, known as a response element, which functions as a sort of genomic address to elicit transcription of the specified gene (Ham et al., 1988). In contrast to the AF-1 domain, the AF-2 domain confers the ability to bind ligand (Gronemeyer et al., 1987). Furthermore, this domain also contains a nuclear localization sequence (GuiochonMantel et al., 1989) and a sequence region allowing for efficient homodimerization or heterodimerization (Kumar and Chambon, 1988). Therefore, the AF-2 functional domain is responsible for ligand binding, dimerization, and also the translocation of the dimer into the nucleus. The presence of these two functional domains defines the family of nuclear receptors and allows for their unique ability to act as ligand-binding transcription factors.

\section{Progesterone receptor isoforms}

In addition to its nuclear receptor function, the PGR demonstrates increased complexity and specificity as it functions via two distinct isoforms, the PGR-A and PGR-B isoforms. These isoforms are transcribed from the same gene (Conneely et al., 1989, Kastner et al., 1990). The PGR isoforms are highly similar except that the PGR-B isoform exhibits an extra 164 amino acids at the amino terminus (see Fig. 1). Within this sequence resides an extra activation domain known as AF-3 which bestows unique functions to the PGR-B isoform (Sartorius et al., 1994). The human PGR isoforms exhibit different transcription abilities within in vitro cell culture experiments. The PGR-A isoform was identified to exhibit a trans-dominant repressive role on gene transcription, while PGR-B often promoted the transcription of genes (Vegeto et al., 1993). Although the human PGR isoforms are highly conserved, this repressive activity of the PGR-A isoform is unique to the human and has not been observed in all species (Giangrande et al., 1997). To further understand this unique function of PGR-B compared to PGR-A, a scrutinized investigation of the activation domains was performed. Indeed, a transcription inhibitory domain was identified within the AF-1 domain of both isoforms (Giangrande et al., 1997). The presence of this domain was identified to result in transcription repression, as demonstrated by the PGR-A isoform. However, since both of the PGR isoforms contain the inhibitory domain, the question left to ask was, "Why are the transcriptional activities of the isoforms so different? Could the extra sequence within PGR-B affect the inhibitory domain found in the AF-1 domain?" Although both PGR isoforms contain the inhibitory domain, the presence of the AF-3 domain successfully prevents the functioning of the inhibitory domain, rendering PGR-B more transcriptionally active (Giangrande et al., 1997, Sartorius et al., 1994). The mechanism of inhibition of the inhibitory domain by the AF-3 domain was identified as a single phosphorylated serine residing within the AF-1 domain (Clemm et al., 2000). Therefore, the presence of the AF-3 domain proved to be responsible for the positive transcriptional activity of the PGR-B isoform.

Within the mouse, the PGR isoforms have also proven to display distinct functions. In vivo studies of the PGR originated with the generation of the PGR ablation mouse model or PRKO mouse. These mice exhibited infertility due to defects in mating behavior, ovulation, and uterine function (Lydon et al., 1995). Furthermore, these mice displayed defects in mammary gland development and ductal side-branching. In order to discern which PGR isoforms were critical for these important reproductive functions, mouse models resulting in the ablation of the individual PGR isoforms were generated. Upon ablation of the PGR-A isoform, the mouse 
resembled the PRKO mouse, displaying infertility with defects in uterine and ovarian function (Mulac-Jericevic et al., 2000). However, the PGR-B ablation mouse model was found dispensable for uterine function, yet necessary for normal mammary development and branching (Mulac-Jericevic et al., 2003). Therefore, although highly similar, the PGR isoforms have demonstrated to be responsible for different functions within the murine reproductive system.

In addition to the PGR-A and PGR-B isoforms, it is thought that a third PGR isoform exists, known as the PGR-C isoform (Wei and Miner, 1994). This isoform was identified to be transcribed from a start site 430 amino acids downstream of the PGR-A start site, resulting in the transcription of a $60 \mathrm{kD}$ protein (graphically displayed in Fig. 1). Due to its absent amino terminus, PGR-C lacks the AF-1 and DNA binding domains, but retains ligand binding and dimerization capabilities (Wei et al., 1997). Therefore, although PGR-C is unable to bind DNA to regulate transcription directly, it may play a role in the sequestration of ligand or other PGR isoforms to decrease the functionality of global progesterone signaling. Conversely, PGR-C has been shown to promote the transcriptional activity of the other PGR isoforms (Wei et al., 1996). Indeed, PGR-C was identified to successfully heterodimerize with PGR-B (Wei et al., 1997). Despite the absence of a DNA binding domain, it is hypothesized that PGR-C may functionally bind DNA as a heterodimer as it is found in the nucleus within human tissue (Wei and Miner, 1994). Within in vitro studies, the PGR-C heterodimer was recognized to successfully bind DNA, although not as efficiently as the PGR-B homodimer (Wei et al., 1997). In the clinic, PGR-C was upregulated within human myometrium at the time of parturition, suggesting that this isoform may play a specific role in the induction of labor (Condon et al., 2006). Nevertheless, PGR-C has often proven difficult to detect which may be due to the transcription start site residing in an inactive transcriptional region (Samalecos and Gellersen, 2008). As a result, much debate has centered on whether or not the PGR-C isoform exists. Therefore, further experiments are required to confirm the
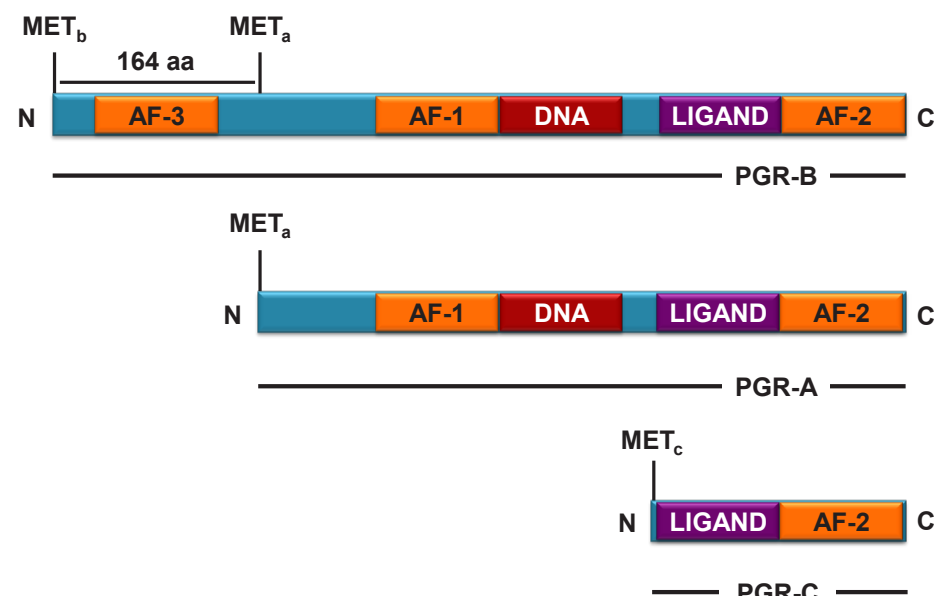

Fig. 1. Progesterone receptor isoforms. The $P G R$ isoforms are transcribed from the same gene due to three separate start sites located within the PGR locus. The PGR-B isoform is the largest of the three isoforms and exhibits an extra amino transactivation domain known as AF-3. As a nuclear receptor, the PGR harbors DNA binding and ligand binding domains. The presence of these domains and the activation domains ( $A F-1, A F-2$, and $A F-3$ ) allow for the unique function of the individual PGR isoforms. aa, amino acid; MET, methionine. existence and function of the PGR-C isoform.

\section{Recruitment of coregulators by the progesterone receptor}

It is known that classical nuclear receptor signaling involves binding ligand, dimerizing with another receptor, and binding to response elements within promoters to recruit or prevent the binding of transcriptional machinery to modulate the transcription of target genes (reviewed in (DeMayo et al., 2002)). Although most transcriptional machinery is generic and can be recruited to multiple sites of transcription, there are molecules recruited along with the generic machinery to promote or repress transcription known as coactivators and corepressors, both types generally termed coregulators (reviewed in (McKenna and O'Malley, 2002)). Interestingly, it was identified that the PGR isoforms recruit specific coregulators to the transcription start site to elicit a transcriptional response (Giangrande et al., 2000). Within the human, PGR-A represses transcription of target genes due to the active inhibitory domain (Vegeto et al., 1993). Therefore, it is not a surprise that the PGR-A isoform preferentially recruits the corepressor, NCOR2 (Giangrande et al., 2000). However, the PGR-B isoform, known to be transcriptionally active in the human, was identified to specifically recruit coactivators such as NCOA1 and GRIP1. Therefore, the $\mathrm{PGR}$ isoforms are able to distinctively regulate transcription through their unique structures and preferential recruitment of coregulators.

The nuclear receptor coactivator (NCOA) family is a family of coactivators successfully recruited by a number of nuclear receptors including the PGR (reviewed in (McKenna and O'Malley, 2002)). Through the generation of knockout mouse models, NCOA1 and NCOA2 have proven to be critical for pregnancy. A total ablation model for NCOA1 was generated via gene targeting mechanisms (Xu et al., 1998). Although the Ncoa1\% mice were viable and fertile, they exhibited a decreased decidual response and reduced uterine wet weight when treated with estrogen. Therefore, these mice exhibited decreased sensitivity to treatment with ovarian hormones. In the uterine specific ablation mouse model of Ncoa2 utilizing a Cre recombinase targeted to the Pgr locus (Soyal et al., 2005), NCOA2 demonstrated to be necessary for fertility (Mukherjee et al., 2006). Upon further investigation, these mice were deemed infertile due to the failure of embryo attachment and an impaired decidual response. Interestingly, these mice were crossed to the Ncoa1\% mice, resulting in a double Ncoa1/ Ncoa2 knockout within PGR positive cells. These dual knockout mice completely failed to elicit a decidual response. Therefore, NCOA1 and NCOA2 together play a significant role in the induction of decidualization through the modulation of progesterone signaling at the transcription level.

\section{Progesterone receptor ligand binding}

The PGR protein primarily binds progesterone ligand. However, the PGR is able to successfully bind synthesized compounds that mimic the progesterone molecule and fit the PGR binding pocket. These compounds, known as progesterone receptor modulators (PRMs) can act in either an inhibitory or stimulatory manner to PGR function (reviewed in (Spitz, 2003)). PRMs have proven useful in controlling abnormal uterine bleeding, the treatment of endometrial disease, contraception, and hormone replacement therapy. The most well-known PRM is RU486 or mifepristone. RU486 was first identified as a PGR antagonist in the early 1980s (Herrmann et al., 1982). However, the use of 
PRMs often results in detrimental side effects which can include non-specific androgenic and glucocorticoid activities (Sitruk-Ware, 2004, Spitz, 2003). To avoid these side effects, compounds that have the ability to act in a dual inhibitory and stimulatory manner were synthesized. These complex compounds are known as selective progesterone receptor modulators (SPRMs) (reviewed in (Chwalisz et al., 2005, Smith and O'Malley, 2004)). Since then, multiple agonists and antagonists have been identified for progesterone signaling. Second generation antagonists such as Proellex, Ulipristal, and Lonaprisan have been utilized in clinical trials for the treatment of leiomyoma, endometriosis, and breast cancer (reviewed in (Spitz, 2009)). Additionally, Asoprisnil, a second generation SPRM, exhibits both stimulatory and inhibitory functions that has proven successful in clinical trials for leiomyoma (Chwalisz et al., 2004, Chwalisz et al., 2007) and is promising for the treatment of endometriosis (reviewed in (Chwalisz et al., 2005)). Although PRMs or SPRMs are engineered to interact with the ligand binding pocket, they exhibit no effect on the removal of chaperone proteins, the dimerization of PGR, or the binding of PGR to DNA (reviewed in (Chabbert-Buffet et al., 2005)). Instead, these modulators affect the post-translational modification of the PGR and oversee the recruitment of certain coregulators, whether corepressor or coactivator (reviewed in (Smith and O'Malley, 2004)). The widespread benefit of these compounds can be applied for the efficient means of contraception, however these molecules have consistently proven to be beneficial in the treatment of women with endometrial disease. Increased understanding of how the existing PRMs and SPRMs function as well as the development of new compounds can aid in the progress and evolution of better treatment therapies for uterine disease. Further discussion regarding the treatment of uterine disease using PRMs will be briefly described in the latter part of this review.

\section{Progesterone receptor response ele- ments}

Upon binding ligand, dimerizing, and entering into the nucleus, the nuclear receptor dimer binds to recognition sequences known as response elements. Nuclear receptor proteins have their own response elements, but at times, can cross-react with other response elements (reviewed in (Gronemeyer, 1991)). Although response elements for a particular nuclear receptor, such as the PGR have a specific sequence motif, there is room for flexibility within the sequence. The progesterone response elements or PREs usually consist of a palindromic hormone response element of AGAACAnnnTGTTCT (Ham et al., 1988). However, PGR binding is not limited to the full PRE. Indeed, it was determined that PGR can bind to promoters of known progesterone target genes such as Lifr, Gata2, Cyp26a1, and Ihh with just half the sequence of the normal PRE (Rubel et al., 2012). Additionally, it was identified that PGR can also bind promoters of known target genes Egfr and Wnt7a with no PRE present (Rubel et al., 2012). Therefore, the rules governing the binding of the PGR at specific sites are ambiguous. Further work is required to identify other response elements in which PGR is able to successfully bind.

\section{Non-genomic functions of the progesterone receptor}

Canonical progesterone signaling requires the presence of nuclear localization and export sequences on the PGR protein for movement in and out of the nucleus (reviewed in (Mulac-Jericevic and Conneely, 2004)). Therefore, the PGR protein is able to readily participate in non-canonical activity within the cytoplasm. Utilizing human and monkey cells in vitro, both PGR isoforms were identified to uniquely interact with $\mathrm{SH} 3$ domains found on Src kinasecontaining membrane receptors (Boonyaratanakornkit et al., 2001). This unique ability of the PGR to interact with $\mathrm{SH} 3$ domains is due to the presence of a polyproline motif that lies upstream of the AF-1 domain. Upon treatment with progesterone, the PGR was identified to bind to the SH3 domain-containing protein, c-Src kinase. The interaction between PGR and c-Src kinase resulted in the efficient activation of MAPK. Therefore, addition of progesterone can result

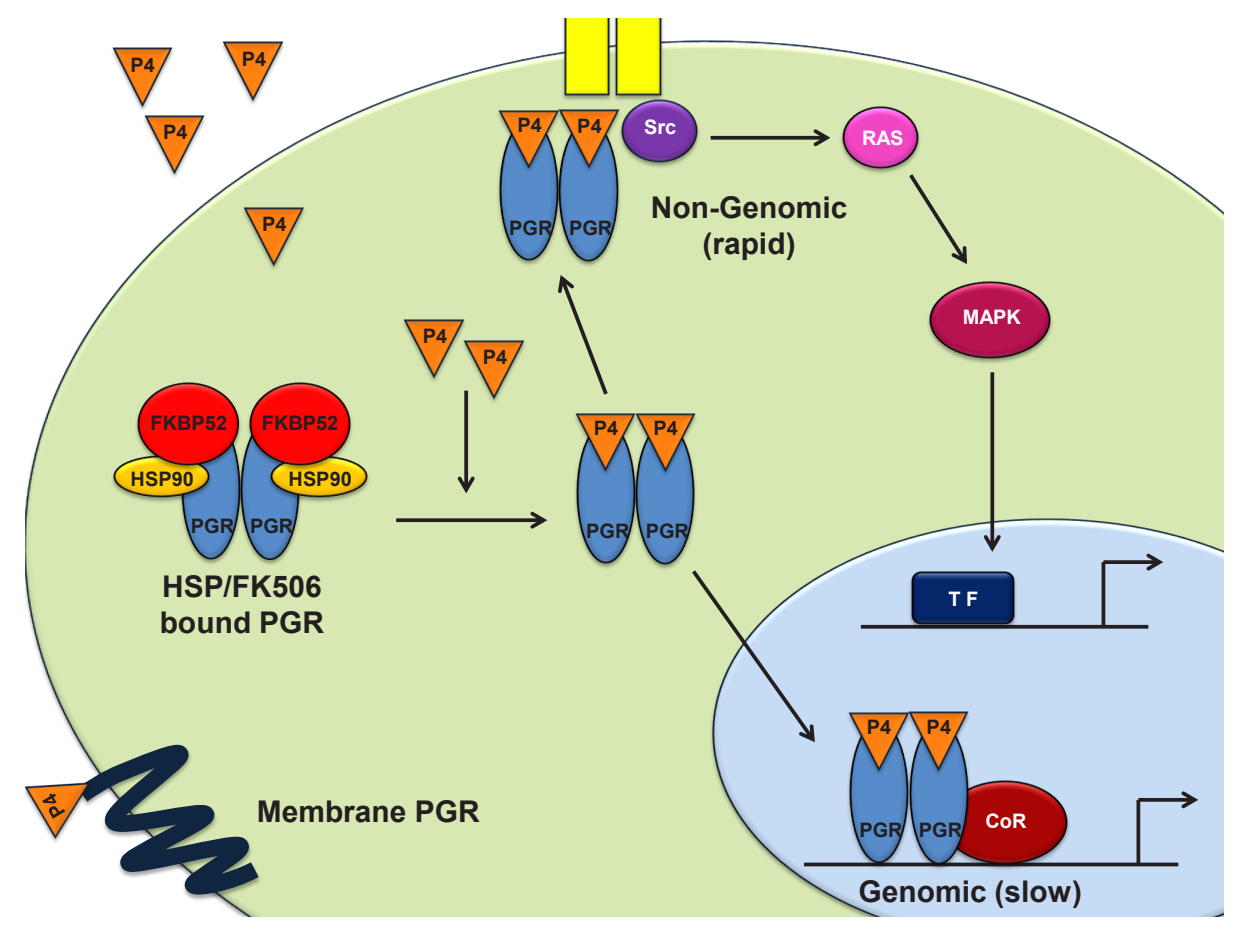

Fig. 2. Progesterone receptor signaling. The PGR operates via multiple signaling pathways within the cell. Canonical progesterone signaling requires the presence of progesterone ligand and the release of the PGR by chaperone proteins. Upon release and binding of progesterone ligand, the dimerized PGR enters the nucleus and binds to response elements within promoter regions and governs the recruitment of transcription coregulators. This genomic signaling method is the slowest of the progesterone signaling mechanisms. The PGR can also function in a non-genomic context through the binding of SH3-domain containing proteins such as Src kinase on specific membrane receptors. The binding of the PGR to Src kinase elicits rapid activation of the RAS/RAF/MAPK pathway within the cell. Also, progesterone receptors integrated into the membrane were found to elicit rapid activation of cellular signaling pathways upon binding of extracellular ligand. Abbreviations: $P 4$, progesterone; PGR, progesterone receptor; CoR, coregulator; TF, transcription factor; MAPK, mitogen activated kinase-like protein; HSP90, heat shock protein 90; FKBP52, FK506 binding protein 4. 
in the rapid promotion of Src kinase, RAS, and the MAPK pathway resulting in a pro-growth cellular signal, depicted in Fig. 2.

Besides the typical nuclear PGR, previous investigations have described the existence of progesterone receptors spanning the cellular membrane, known as membrane progesterone receptors (not to be confused with PGRMC1 and PGRMC2). There are three speculated membrane progesterone receptor isoforms: $\mathrm{mPR} \alpha$, $\mathrm{mPR} \beta$, and mPR $\gamma$ (Zhu et al., 2003a, Zhu et al., 2003b). Although structurally different from nuclear PGR, these receptors share many commonalities with the GPCR family of transmembrane proteins. Interestingly, the $\mathrm{mPR} \alpha$ and $\mathrm{mPR} \beta$ forms were identified to bind to progestins and rapidly promote the MAPK pathway in mammalian breast cancer cells (Hanna et al., 2006). Furthermore, when expressed in yeast, the membrane progesterone receptors successfully elicit a response upon treatment with progestins (Smith et al., 2008). These membrane proteins are also thought to play a role in eliciting contraction in parturition (Karteris et al., 2006). However, many of these studies have not been corroborated. Therefore, future work is required to confirm the existence, ligand binding ability, and functionality of these membrane progesterone receptors (further discussion found in (Gellersen et al., 2009)).

\section{Ligand independent functions of the progesterone receptor}

Canonical progesterone signaling states that a dimerized receptor and ligand is necessary for active signaling. However, previous studies have shown that the PGR can function in elaborate ways independent of ligand. In the absence of ligand within human breast cancer cells, the PGR was shown to interact with a complex of proteins to collectively repress chromatin (Vicent et al., 2013). Upon addition of ligand, the repressive complex breaks free of the chromatin, allowing for immediate transcription to take place. Also within human breast cancer cells, the PGR-B isoform was found to specifically promote cell migration in the absence of ligand (Bellance et al., 2013). Surprisingly, upon the addition of progesterone, PGR-B ceased exhibiting a pro-migratory effect. The induction of migration resulted from the activation of focal adhesion kinase by the PGR-B isoform in the absence of ligand. Interestingly, the PGR-A isoform was shown to promote PGR-B's role in the induction of migration, yet the PGR-A isoform alone was unable to induce migration. Lastly, utilizing the established PRKO mouse model as a control (Lydon et al., 1995), the PGR in the absence of ligand successfully promoted a lordosis response upon treatment with a dopamine agonist in vivo (Mani et al., 1996). Therefore, the involvement of the PGR in the promotion of cell migration, repression of chromatin, and induction of lordosis in the absence of ligand are novel functions in global progesterone signaling and validate the PGR as a supervisor of many diverse signaling mechanisms.

\section{Regulation of progesterone receptor activity}

Prior to the presence of progesterone ligand in the extracellular space, the PGR protein resides within the cytoplasm. As the PGR waits for the ligand, it is bound by multiple proteins to preserve its activity, functionality, and rapid response (reviewed in (Mulac-Jericevic and Conneely, 2004)). These proteins consist of heat shock protein, HSP90, a p23 chaperone protein, and one of four chaperones containing a tetratricopeptide repeat (TPR) domain (reviewed in (Pratt and Toft, 1997)). One of these TPRcontaining domain chaperone proteins is FKBP52, known to bind and promote the activity of the PGR (Barent et al., 1998). The importance of FKBP52 function in the activity of the PGR was demonstrated via murine gene ablation techniques. A mouse model was designed to completely ablate the Fkbp 4 gene which encodes the FKBP52 protein utilizing gene targeting strategies (Cheung-Flynn et al., 2005). Upon total gene ablation of Fkbp4, the female mice displayed complete infertility due to the inability for embryos to attach (Tranguch et al., 2005). Further investigation at the time of implantation revealed that less progesterone ligand was bound by PGR and progesterone target genes were decreased. Furthermore, estrogen target genes were aberrantly upregulated due to impaired progesterone signaling. This suggested that these mice exhibited a dominance of estrogen signaling which prevented normal embryo implantation.

Later experiments were performed to ablate Fkbp4 across two different mouse backgrounds, the C57BL/6J and CD1 (Tranguch et al., 2007). Interestingly, upon treatment with progesterone, embryo implantation was rescued in mice from the CD1 background. Furthermore, mice from only the CD1 background were able to decidualize properly and carry pups to term when supplied with progesterone daily from day 2 of pregnancy until day 17 . Therefore, despite the lack of FKBP52, the excessive administration of progesterone ligand was able to rescue the infertility of mice from the CD1 background. This confirms the important role of FKBP52 in the potentiation of PGR activity. This novel finding also suggests the importance of genetic background in the regulation of progesterone signaling via the modulation of FKBP52. The presence of genetic variation may shed more light on women suffering from infertility in the clinic.

To add to the complexity of progesterone signaling, the activity of the PGR protein is often regulated via post-translational modifications. Phosphorylation of the PGR protein has been extensively studied in human breast cancer cells. According to these studies, the PGR protein contains 7 confirmed phosphorylation sites (Zhang et al., 1997, Zhang et al., 1994, 1995). Of these 7 known serine phosphorylation sites, 3 are located exclusively in the PGR-B protein region (Zhang et al., 1994, 1995). The remaining 4 sites are found in both PGR-A and PGR-B (Zhang et al., 1997, Zhang et al., 1995). Of the 7 total PGR phosphorylation sites, 4 of these sites are basally phosphorylated at all times, yet can be induced by the administration of hormone (Zhang et al., 1997). The other 3 sites are exclusively induced by the presence of hormone. The presence of phosphorylated serines can modulate the activity of the PGR protein in a stimulatory or inhibitory manner. Interestingly, the presence of phosphorylation site Ser294, found within both PGR isoforms, was only phosphorylated in the PGR-B protein (Clemm et al., 2000). This serine was found to reside within the PGR inhibitory domain. Therefore, it was concluded that the phosphorylated Ser294 on the PGR-B protein resulted in the inhibition of the inhibitory domain and active transcription ability of human PGR-B over PGR-A. In addition to phosphorylation, an acetylation site was identified within the hinge region of the PGR protein (Daniel et al., 2010). The presence of this particular acetyl group was identified to regulate nuclear shuttling efficiency and phosphorylation rate, ultimately affecting the transcriptional response of the PGR. Additionally, depending on the promoter context, the PR-B isoform is negatively regulated 
by SUMOylation resulting in decreased hormone sensitivity and a decrease in overall transcriptional activity (Abdel-Hafiz et al., 2009). Therefore, post-translational modifications of the PGR are important for the regulation of transcription activity and can be induced upon addition of ligand. (A recent detailed discussion of the post translational modifications of the PGR can be found in the following: (Abdel-Hafiz and Horwitz, 2014)).

In conclusion, progesterone signaling is governed by the highly specialized PGR protein consisting of multiple domains, activated by ligand. The ligand-bound PGR protein functions to bind DNA and activate or inhibit the transcription of target genes. To add further specificity to progesterone signaling, at least two isoforms are transcribed from the Pgrgene, resulting in completely different transcriptional functions due to dimerization status, recruitment of specific coregulators, and an active inhibitory domain. Also, the PGR protein is able to bind to SH3 domains to rapidly activate signaling pathways irrespective of DNA binding. Furthermore, membrane-spanning versions of the progesterone receptor may exist and demonstrate completely different functions compared to their nuclear counterparts. Recent studies have described multiple ligand independent roles of PGR in the promotion of migration and repression of chromatin. A few of these many PGR mechanisms are graphically depicted in Fig. 2. Finally, PGR activity is regulated by many mechanisms including the binding of chaperone proteins within the cytoplasm and the addition of post-translational modifications.

\section{Progesterone receptor function during early pregnancy}

The murine uterus is composed of multiple compartments including the outer myometrium, made up of two muscle layers, the inner stroma containing the endometrial glands, and the inner luminal epithelium. Located within all major compartments of the endometrium, the PGR protein has continually demonstrated to be essential for pregnancy. Without functional progesterone signaling, pregnancy is unable to progress, as was demonstrated in the PRKO mouse which exhibited infertility due to defects in mating behavior, ovulation, and decidualization (Lydon et al., 1995). Through the utilization of genetically engineered mouse models, the PGR has proven itself as a major transcriptional regulator of genes involved in uterine function. Indeed, progesterone signaling is known to regulate pathways involved in postnatal uterine development, implantation, decidualization, and parturition. This portion of the review will provide a brief overview of progesterone regulated pathways during early implantation.

The steroid hormones, estrogen and progesterone, and their cognate receptors work in concert to regulate early pregnancy. Progesterone signaling functions in an inhibitory manner to the estrogen signaling pathway (Hsueh et al., 1975). This inhibitory relationship between the two hormone pathways provides an important regulatory pattern necessary for early implantation. Early ovulatory secretion results in high estrogen levels at day 1 and 2 of pregnancy (reviewed in (Cha et al., 2012)). As the corpora lutea is maintained within the ovary, progesterone is secreted, resulting in the inhibition of estrogen target genes within the uterus, such as mucin 1 (Muc1). MUC1 is a glycosylated protein that lines the uterine epithelium and functions as a mucinous barrier to bacteria, pathogens, and other foreign substances (reviewed in (Carson etal., 2000)). With the release of the egg and fertilization of the embryo within the oviduct, this mucinous layer must be removed to allow for the embryo to come into contact with the epithelium. Activated by estrogen early in pregnancy, MUC1 is soon downregulated following the spike in epithelial PGR levels by day 3 of pregnancy, allowing for proper attachment and invasion of the epithelium by the embryo. Although most epithelial estrogen target genes are suppressed at days 2-3 due to high levels of progesterone, the epithelial PGR decreases in expression in the epithelium by day 4 , initiating the start of the "window of receptivity" and permitting the nidatory estrogen surge. This spike in estrogen secretion promotes the production of leukemia inhibitory factor (LIF) within the endometrial glands and results in the implantation of the embryo via the LIF-STAT3 signaling pathway (reviewed in (Cha et al., 2012)). The progression from estrogen-induced to progesterone-induced genes within early implantation is displayed graphically in Fig. 3.

At the time of implantation, many factors within the epithelium and stroma are coordinated to receive the implanting embryo. These factors, many of which are progesterone target genes, contribute to proper implantation in the uterine epithelium and the resultant decidual response in the surrounding stroma. Genes known to be induced by progesterone, Hoxa10 and Hoxa11 were identified to be critical for pregnancy utilizing murine ablation models. Upon ablation of Hoxa10, female mice exhibited infertility due to maternal defects in embryo implantation and decidualization (Benson et al., 1996). Upon further investigation, it was identified that prostaglandin receptors Ep3 and Ep4 were downregulated in Hoxa10 null mice (Lim et al., 1999). Additionally, cyclooxygenase 2 or COX2 expression was impaired in these mice during late post-implantation. COX2 is the rate-limiting step enzyme in the synthesis of prostaglandins (reviewed in (Smith et al., 1996)). These uterine defects and decreased COX2 expression suggest the presence of a dysfunctional prostaglandin pathway leading to the impairment of implantation.

Hoxa11 null mice displayed similar defects in embryo implantation compared to their Hoxa10 counterparts. HOXA11 is normally expressed in the underlying stroma of the blastocyst attachment site (Gendron et al., 1997). Upon complete ablation of this gene, mice exhibited decreased uterine size, a decreased number of glands, and a defective decidual response. The Hoxa11 null mice also demonstrated decreased LIF at the time of implantation which was attributed to the reduced number of endometrial glands. Both HOXA10 and HOXA11 have shown to be critically important for early embryo apposition and initiation of the stromal decidual response. It is not a surprise that these HOX genes were found expressed within human endometrium during implantation (Taylor et al., 1998, Taylor et al., 1999).

Decidualization consists of the initial proliferation of stromal cells and differentiation into decidual cells to support the growth of the embryo. This process is controlled by critical target genes downstream of the PGR. Before the time of embryo implantation, epithelial PGR activates the expression of multiple genes in the epithelial compartment allowing for embryo attachment to take place (Franco et al., 2012). One of these critical epithelial targets is indian hedgehog $(I h h)$. Known to be indispensable for embryo attachment (Lee etal., 2006), IHH is first expressed in the epithelium and then signals downstream within the uterine stroma to promote decidualization. One particular stromal gene activated downstream of $\mathrm{IHH}$ is the nuclear receptor subfamily 2 , group $\mathrm{F}$, member 2 (Nr2f2) (also known as COUP-TFII) (Lee et al., 2006). Much of the 
information obtained regarding the signaling mechanisms leading up to embryo implantation and stromal decidualization is due to the efficient utilization of genetically engineered mouse models. A total knockout mouse model of Nr2f2 was generated and the mouse exhibited perinatal lethality due to the necessary role of NR2F2 in cardiac development (Pereira et al., 1999). However, heterozygote knockout mice suggested that NR2F2 may play an important role in the uterus (Takamoto etal., 2005). Upon expression analysis, NR2F2 was observed to be specifically expressed within the uterine stroma and was therefore hypothesized to be critical for decidualization. A conditional knockout allele was soon generated and upon mating to the Pgrcre recombinase mouse (Soyal et al., 2005), Nr2f2 was efficiently ablated in the uterus (Kurihara et al., 2007). Despite its stromal-specific expression, conditional ablation of Nr2f2 not only resulted in defects in stromal decidualization, but also in embryo attachment. NR2F2 was identified to regulate stromal decidualization through the activation of critical decidual target genes, Wnt4 and Bmp2. Interestingly, NR2F2 was determined to signal back to the epithelium to inhibit estrogen signaling before the time of embryo implantation (graphically displayed in Fig.3). Therefore, NR2F2 acts as a conduit from epithelial IHH to not only elicit the activation of decidual genes, but also feedback on the epithelial compartment to contribute to the induction of uterine receptivity.

To add further complexity to the regulation of implantation via compartmental cross-talk, a stromal progesterone target, heart and neural crest derivatives expressed 2 or HAND2 was identified to be necessary for embryo implantation (Li et al., 2011). Through the generation of a uterine specific knockout mouse for Hand2, it was determined that Hand2 ablation resulted in infertility with defects in embryo attachment. Upon further investigation, HAND2 was found to inhibit FGF ligands within the stroma which feedback on the epithelium to promote estrogen signaling. The FGFs signal through the MAPK pathway to promote epithelial estrogen signaling resulting in increased expression of MUC1 and induction of epithelial proliferation (depicted in Fig. 3). Therefore, although expressed in the stroma, HAND2 acts as an inhibitor of epithelial estrogen signaling allowing for the preparation of the uterine epithelium for the reception of the embryo.

Within the uterine stroma, NR2F2 promotes the expression of BMP2 in preparation for the start of decidualization. Upon conditional ablation of Bmp2 in the uterus, the mice exhibited infertility with defects in decidualization (Lee et al., 2007). Interestingly, it was demonstrated that these mice undergo normal embryo attachment, yet exhibit major defects in decidualization. Although proliferation appeared normal within these mice at the onset of decidualization, by 48 hours after the decidual stimulus the stroma exhibited minimal proliferation suggesting that BMP2 is important for the secondary round of proliferation within the decidual response. Furthermore, upon staining with alkaline phosphatase, the uterine stroma displayed minimal levels of differentiation. However, this stromal cell differentiation defect was partially rescued upon intraluminal uterine injection of recombinant BMP2 at the onset of decidualization. This rescue experiment confirmed the important role of BMP2 in the induction of decidual differentiation. Upon performing microarray analysis of this mouse model, it was determined that BMP2 regulates non-canonical WNT ligands, WNT4 and WNT6 at the time of decidualization. Furthermore, BMP2 was also observed to regulate FKBP proteins which function to modulate the activity of the PGR. Therefore, BMP2 signaling is necessary for decidualization through the promotion of non-canonical WNT signaling and the regulation of PGR activity.

Canonical WNT signaling consists of WNT ligands binding to a FRIZZLED membrane receptor, resulting in the sequestration of molecules known to bind and inhibit $\beta$-CATENIN (reviewed in (Angers and Moon, 2009)). Due to the sequestration of $\beta$-CATENIN inhibitors, $\beta$-CATENIN is free to enter the nucleus and promote the activation of transcription factors within the LEF/TCF family. Noncanonical WNT ligands operate via different membrane receptors to elicit cellular mechanisms independent of $\beta$-CATENIN (reviewed in (Angers and Moon, 2009)). The method of binding to extracellular
Fig. 3. Progesterone receptor signaling through the implantation window. On day 2 of pregnancy, MUC1 coats the lining of the proliferative uterine epithelium due to active estrogen signaling. By day 3, the PGR is expressed at high levels within the uterine epithelium activating downstream stromal target NR2F2 through the indian hedgehog ligand (IHH). NR2F2 promotes the induction of HAND2 and inhibits estrogen signaling within the epithelium leading to decreased expression of MUC1 and reduced epithelial proliferation. At the time of implantation on day 4 of pregnancy, NR2F2 activates BMP2 in the preparation of the stroma for decidualization. HOXA11 accumulates in the stroma near the sites of embryo attachment. HOXA10 also increases in the stroma at the start of decidualization. Abbreviations: $P G R$, progesterone receptor; ESR1, estrogen receptor; FGF, fibroblast growth factor; NR2F2, nuclear receptor subfamily 2, group $F$, member 2; HAND2, heartand nerual crest derivatives expressed transcript 2; BMP2, bone morphogenetic protein 2; WNT4, wingless-related MMTV integration site 4; MAPK, mitogen activated kinase-like protein; HOXA10, homeobox A10; HOXA11, homeobox A11.

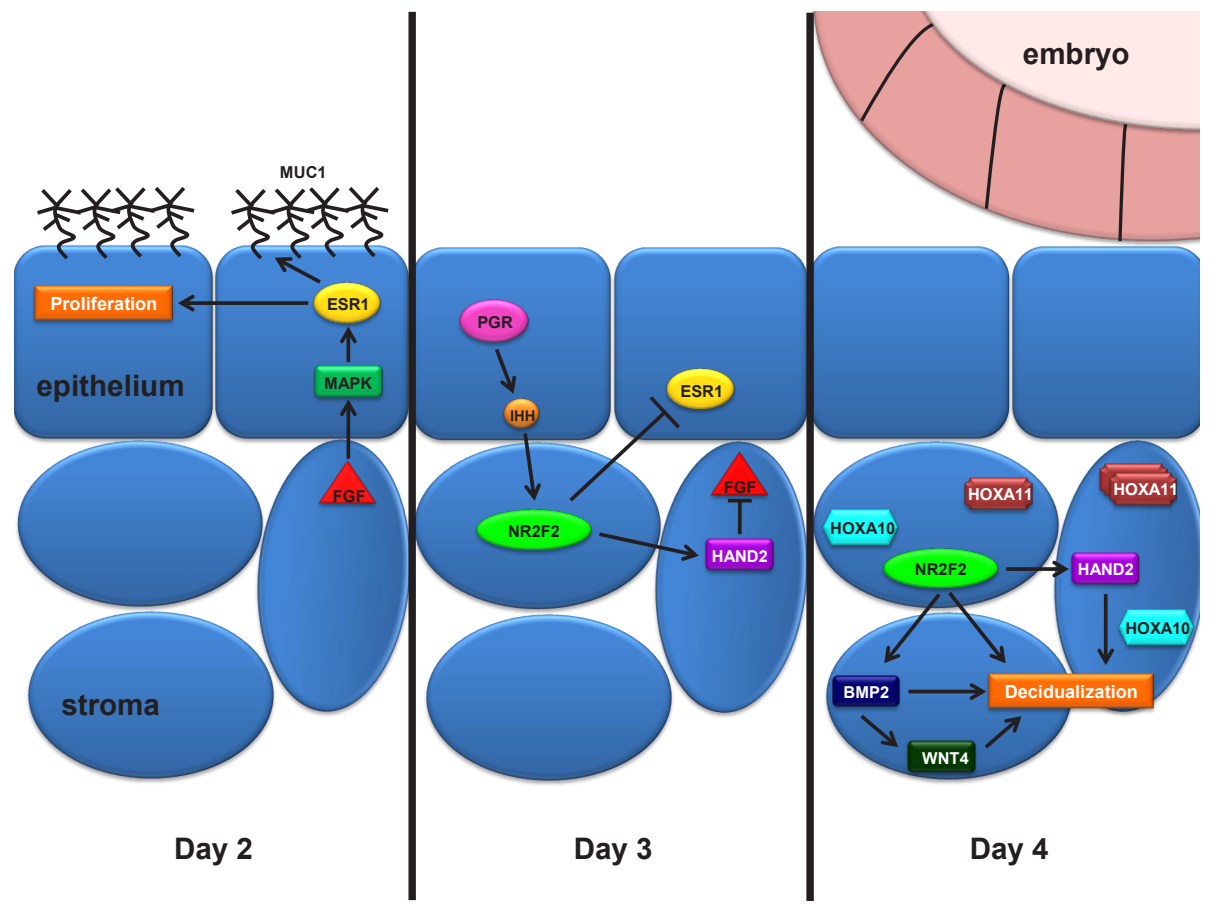


membrane proteins allows WNT ligands to activate coordinated signaling patterns within large groups of cells in an organ. Indeed, WNT ligands are able to function via crosstalk between the epithelial and stromal compartments of the uterus. Activated downstream of NR2F2 and BMP2 within the uterine stroma, WNT4 was determined to be a critical factor for post implantation uterine function. Upon conditional ablation of Wnt4 within the mouse uterus, the mice exhibited a failure of embryo attachment and the absence of a decidual response (Franco et al., 2011). Initially, these defects were thought to arise from the absence of glands which are critical for secreting the growth factor, LIF. However, intraluminal uterine injection of recombinant LIF failed to rescue decidualization within the Wnt4 null mice. Therefore, WNT4 itself is necessary for decidualization and embryo implantation.

\section{Targeting the progesterone receptor for the treatment of uterine disease}

This review has examined PGR structure, function, and regulation as a nuclear receptor and briefly described its necessary role in the initiation and continuance of pregnancy. The remainder of this review will switch gears to focus on the role of progesterone signaling in endometrial disease. Expanding our knowledge of basic progesterone signaling within the uterus is important, yet this knowledge generates lasting impact when it is applied to the development of new therapies to help treat women suffering from endometrial disease. Women today suffer from a variety of reproductive tract-associated diseases. This review will describe the most prevalent uterine diseases, specifically endometrial cancer, endometriosis, and leiomyoma.

Endometrial cancer is a detrimental and at times deadly uterine disease with an expected 46,000 new cases and about 8,000 deaths in 2011 (Siegel et al., 2011). Although the most common endometrial cancer is adenocarcinoma, endometrial sarcoma can occur. Due to its prevalence, much knowledge has been gained in the field of endometrial adenocarcinoma. Cases of adenocarcinoma can be divided into two groups (Bokhman, 1983). The first group consists of an estrogen responsive tumor, thought to arise from treatment with unopposed estrogens. The second group is able to grow independently of estrogen while exhibiting poor differentiation (reviewed in (Sherman, 2000)). Women presenting with adenocarcinoma from the second group often fail to respond to hormone therapy and are usually given a poor prognosis. The positive expression of the steroid hormone receptors usually indicates the high differentiation state of the tumor and the ability to effectively respond to hormone treatment. Indeed, high expression of the PGR correlated with low tumor grade and low recurrence rate, while expression of ESR1 also correlated with low recurrence rate (Ehrlich et al., 1988). More recent studies have corroborated this data, reporting that the expression of the PGR isoforms inversely correlates with tumor grade (Arnett-Mansfield et al., 2001). Furthermore, although normal human endometrium expresses both PGR isoforms (Mote et al., 1999), loss of expression of one isoform is considered an early event in the development of endometrial carcinoma (Arnett-Mansfield et al., 2001). Interestingly, studies have provided conflicting evidence suggesting the role of the PGR-B isoform in the exacerbation of endometrial cancer. Expression of the PGR-B isoform was suggested to positively correlate with tumor grade in endometrial, ovarian, and cervical cancers (Fujimoto et al., 1995), yet loss of PGR-B was also identified in poorly differentiated endometrial cancers (Kumar et al., 1998, Saito et al., 2006, Sakaguchi et al., 2004). Therefore, the role of the PGR-B isoform in promoting endometrial cancer is controversial.

Typical treatment for women suffering from endometrial cancer involves a hysterectomy and bilateral salpingo-oophorectomy. However, pre-menopausal women often opt out of this treatment plan in order to maintain their fertility (discussed in (Gunderson et al., 2012)). Therefore, the development and utilization of PRMs or SPRMs is necessary in the treatment of this disease. Clinical trials utilizing progesterone agonists also known as progestins, which function to inhibit the extensive proliferation of the epithelium, have exhibited relative success in younger women with high differentiated endometrial carcinoma, but can result in recurrence in a minimal number of women (Kaku et al., 2001, Ramirez et al., 2004, Thigpen et al., 1999, Ushijima et al., 2007). However, combination treatment of a progesterone agonist with tamoxifen may prove to be a more effective treatment for endometrial cancer (Whitney et al., 2004). Although mifepristone has been tested in the treatment of PGR-positive endometrial adenocarcinoma and sarcoma (Ramondetta et al., 2009), future work is needed to corroborate its efficacy. Therefore, the expression of the PGR isoforms and the progesterone signaling status directly affects the tumor grade and severity of disease and can also govern the possible treatment options available to these women suffering from endometrial cancer (discussed further in (Kim et al., 2013)).

Endometriosis is defined as the presence of endometrial tissue outside of the endometrium, occurring in about $10 \%$ of women in the nation today (reviewed in (Giudice and Kao, 2004, Kim et al., 2013)). Endometriosis can occur in different locations throughout the body, but is highly concentrated in the surrounding peritoneal cavity and the ovaries. It is commonly thought that endometriosis initiates upon the exit of endometrial tissue from the fallopian tubes into the peritoneal cavity via retrograde flow of menstrual fluid (discussed in (Giudice and Kao, 2004)). Once the tissue exits the uterus, it attaches and grows on tissues within the peritoneum. Although endometriosis is thought to initiate via retrograde menstrual flow, most women are known to retrograde flow under normal conditions. Therefore, the pathological initiation of endometriosis is still under debate today.

Women with endometriosis experience chronic pain and bleeding which is directly correlated to ovulatory cycling. Since the symptoms and persistence of endometriosis are dependent on the production of the ovarian steroid hormones, anti-hormone therapies such as anti-progestins or inhibitors of estrogen signaling can be utilized to minimize pain and growth of the endometriotic lesions (reviewed in (Olive and Pritts, 2001)). Effective treatment involves the removal of the lesions and inhibition of ovulation or possible oophorectomy. Interestingly, the role of progesterone in the treatment of endometriosis is not clearly defined. Although treatment with mifepristone prevents endometriotic growth (Kettel et al., 1996), clinical trials have identified progestins as an effective pain reducer in women suffering from endometriosis (Vercellini et al., 1997). However, large amounts of progesterone are thought to be secreted by ectopic endometrial lesions (Sun et al., 2003). Therefore, the role of progesterone in the progression of endometriosis is complicated and requires further investigation to determine safe treatment options for women suffering from this detrimental disease. 
Leiomyoma or uterine fibroids are the most common endometrial disease affecting about $80 \%$ of women with occurrence increasing with age (Cramer and Patel, 1990, Parker, 2007). Uterine fibroids are benign tumors arising from the myometrium resulting in pain and uterine bleeding. Due to the general discomfort of this disease, many women opt for surgery to remove the fibroids. In fact, an average of $40 \%$ of all hysterectomies are performed with the intent to remove uterine fibroids (Wilcox et al., 1994). The effect of hormones on the growth of leiomyoma has been controversial. Although estrogen is generally known to potentiate proliferation of uterine tissue, while progesterone often inhibits abnormal growth, it is unclear whether this dogma holds true for leiomyoma (discussed in (Kim et al., 2013)). Treatment with estrogen plus progesterone was found to increase proliferation of leiomyoma over treatment with estrogen alone (Ishikawa et al., 2010, Lamminen et al., 1992). Progesterone treatment alone was identified to both enhance (Hoekstra et al., 2009) and inhibit (Yamada et al., 2004) leiomyoma growth on different occasions in vitro. However, multiple clinical trials have proved the efficacy of PGR antagonists such as mifepristone in the decrease of fibroid size and reduction of symptoms (Carbonell Esteve et al., 2008, Fiscella et al., 2006). Furthermore, the SPRM, Asoprisnil, was effective in the reduction of fibroid size, uterine bleeding, and abdominal pain (Chwalisz et al., 2007). Although the effect of hormone therapy on the growth of leiomyoma is complicated and warrants further investigation, the use of PRMs or SPRMs is a promising option for women suffering from leiomyoma.

\section{Conclusion}

The PGR functions via a dynamic and highly regulated system of interconnected pathways to govern the success of a pregnancy and the overall health of the endometrium. As a nuclear receptor, the PGR is unique in its ability to bind both ligand and DNA to promote the transcription of target genes at the appropriate time. Multiple isoforms are transcribed from the Pgr locus and display unique transcriptional abilities depending on the species. The individual PGR isoforms also exhibit the distinct ability to recruit specific coregulators to sites of transcription. Furthermore, the PGR is able to function rapidly in a non-genomic fashion to promote the MAPK pathway. Additionally, new evidence suggests the presence of distinct membrane progesterone receptors on the cellular surface. Previous studies have also identified unique ligand-independent functions of the PGR. Without ligand, the PGR was identified to increase migration through focal adhesion kinase signaling and successfully repress chromatin through binding to a repressive protein complex. The function and activity of the PGR is regulated by bound chaperone proteins within the cytoplasm that release the PGR only in the presence of progesterone ligand. Furthermore, the PGR isoforms exhibit seven experimentally verified phosphorylation sites which affect the transcriptional ability and recruitment of coregulators to the promoters of genes. This functional diversity and intricate regulation of the PGR provides evidence to its chief role in female reproduction.

The progesterone signaling pathway governs uterine function and fertility via epithelial to stromal crosstalk to initiate embryo implantation and decidualization at the appropriate time. Through the induction of hedgehog signaling via the epithelial PGR, NR2F2 is activated, resulting in the preparation of the stroma for the decidual response and promotion of embryo implantation. At attachment, the HOX proteins promote apposition and implantation of the embryo, allowing for pregnancy to progress. Downstream of NR2F2, BMP2 promotes the differentiation and proliferation of the uterine stromal cells necessary for decidualization and also activates non-canonical WNT ligands to promote stromal cell proliferation. Through these complex mechanisms occurring within both the epithelial and stromal compartment, the PGR tightly regulates the progression of pregnancy.

This knowledge of global progesterone signaling within the uterus is critical for understanding how the PGR functions within endometrial disease. The expression and responsiveness of the PGR within diseased endometrial tissue frequently indicates the prescribed treatment options for the individual patient. An increased understanding of the PGR under normal and diseased states will benefit the development of improved therapies to treat these devastating uterine diseases. Additionally, further identification and utilization of PRMs such as mifepristone and SPRMs such as Asoprisnil will be instrumental in the successful treatment of reproductive-associated disease.

\section{Acknowledgements}

This work was supported by NIH Grants: R01HD042311, 5U54HD007495 (to FJD).

\section{References}

ABDEL-HAFIZ, H., DUDEVOIR, M.L. and HORWITZ, K.B. (2009). Mechanisms underlying the control of progesterone receptor transcriptional activity by SUMOylation. J Biol Chem 284: 9099-9108.

ABDEL-HAFIZ, H.A. and HORWITZ, K.B. (2014). Post-translational modifications of the progesterone receptors. J Steroid Biochem Mol Biol 140: 80-89.

ANGERS, S. and MOON, R.T. (2009). Proximal events in Wnt signal transduction. Nat Rev Mol Cell Biol 10: 468-477.

ARNETT-MANSFIELD, R.L., DEFAZIO, A., WAIN, G.V., JAWORSKI, R.C., BYTH, K., MOTE, P.A. and CLARKE, C.L. (2001). Relative expression of progesterone receptors $A$ and $B$ in endometrioid cancers of the endometrium. Cancer Res 61: 4576-4582.

BARENT, R.L., NAIR, S.C., CARR, D.C., RUAN, Y., RIMERMAN, R.A., FULTON, J., ZHANG, Y. and SMITH, D.F. (1998). Analysis of FKBP51/FKBP52 chimeras and mutants for $\mathrm{Hsp} 90$ binding and association with progesterone receptor complexes. Mol Endocrinol 12: 342-354.

BELLANCE, C., KHAN, J.A., MEDURI, G., GUIOCHON-MANTEL, A., LOMBES, M. and LOOSFELT, H. (2013). Progesterone receptor isoforms PRA and PRB differentially contribute to breast cancer cell migration through interaction with focal adhesion kinase complexes. Mol Biol Cell 24: 1363-1374.

BENSON, G.V., LIM, H., PARIA, B.C., SATOKATA, I., DEY, S.K. and MAAS, R.L. (1996). Mechanisms of reduced fertility in Hoxa-10 mutant mice: uterine homeosis and loss of maternal Hoxa-10 expression. Development 122: 2687-2696.

BOKHMAN, J.V. (1983). Two pathogenetic types of endometrial carcinoma. Gynecol Oncol 15: 10-17.

BOONYARATANAKORNKIT, V., SCOTT, M.P., RIBON, V., SHERMAN, L., ANDERSON, S.M., MALLER, J.L., MILLER, W.T. and EDWARDS, D.P. (2001). Progesterone receptor contains a proline-rich motif that directly interacts with $\mathrm{SH} 3$ domains and activates c-Src family tyrosine kinases. Mol Cell 8: 269-280.

BROSENS, J.J., TULLET, J., VARSHOCHI, R. and LAM, E.W. (2004). Steroid receptor action. Best Pract Res Clin Obstet Gynaecol 18: 265-283.

CARBONELl ESTEVE, J.L., ACOSTA, R., HEREDIA, B., PEREZ, Y., CASTANEDA, M.C. and HERNANDEZ, A.V. (2008). Mifepristone for the treatment of uterine leiomyomas: a randomized controlled trial. Obstet Gynecol 112: 1029-1036.

CARSON, D.D., BAGCHI, I., DEY, S.K., ENDERS, A.C., FAZLEABAS, A.T., LESSEY, B.A. and YOSHINAGA, K. (2000). Embryo implantation. Dev Biol 223: 217-237.

CHA, J., SUN, X. and DEY, S.K. (2012). Mechanisms of implantation: strategies for 
successful pregnancy. Nat Med 18: 1754-1767.

CHABBERT-BUfFET, N., MEDURI, G., BOUCHARD, P. and SPITZ, I.M. (2005). Selective progesterone receptor modulators and progesterone antagonists: mechanisms of action and clinical applications. Hum Reprod Update 11: 293-307.

CHEUNG-FLYNN, J., PRAPAPANICH, V., COX, M.B., RIGGS, D.L., SUAREZ-QUIAN, C. and SMITH, D.F. (2005). Physiological role for the cochaperone FKBP52 in androgen receptor signaling. Mol Endocrinol 19: 1654-1666.

CHWALISZ, K., DEMANNO, D., GARG, R., LARSEN, L., MATTIA-GOLDBERG, C. and STICKLER, T. (2004). Therapeutic potential for the selective progesterone receptor modulator asoprisnil in the treatment of leiomyomata. Semin Reprod Med 22: 113-119.

CHWALISZ, K., LARSEN, L., MATTIA-GOLDBERG, C., EDMONDS, A., ELGER, W. and WINKEL, C.A. (2007). A randomized, controlled trial of asoprisnil, a novel selective progesterone receptor modulator, in women with uterine leiomyomata. Fertil Steril 87: 1399-1412.

CHWALISZ, K., PEREZ, M.C., DEMANNO, D., WINKEL, C., SCHUBERT, G. and ELGER, W. (2005). Selective progesterone receptor modulator development and use in the treatment of leiomyomata and endometriosis. Endocr Rev 26: 423-438.

CLEMM, D.L., SHERMAN, L., BOONYARATANAKORNKIT, V., SCHRADER, W.T., WEIGEL, N.L. and EDWARDS, D.P. (2000). Differential hormone-dependent phosphorylation of progesterone receptor $A$ and $B$ forms revealed by a phosphoserine site-specific monoclonal antibody. Mol Endocrinol 14: 52-65.

CONDON, J.C., HARDY, D.B., KOVARIC, K. and MENDELSON, C.R. (2006). Upregulation of the progesterone receptor $(\mathrm{PR})-\mathrm{C}$ isoform in laboring myometrium by activation of nuclear factor-kappaB may contribute to the onset of labor through inhibition of PR function. Mol Endocrinol 20: 764-775.

CONNEELY, O.M., KETTELBERGER, D.M., TSAI, M.J., SCHRADER, W.T. and O'MALLEY, B.W. (1989). The chicken progesterone receptor $A$ and $B$ isoforms are products of an alternate translation initiation event. JBiol Chem264: 14062-14064.

CRAMER, S.F. and PATEL, A. (1990). The frequency of uterine leiomyomas. Am J Clin Pathol 94: 435-438.

DANIEL, A.R., GAVIGLIO, A.L., CZAPLICKI, L.M., HILLARD, C.J., HOUSA, D. and LANGE, C.A. (2010). The progesterone receptor hinge region regulates the kinetics of transcriptional responses through acetylation, phosphorylation, and nuclear retention. Mol Endocrinol 24: 2126-2138.

DEMAYO, F.J., ZHAO, B., TAKAMOTO, N. and TSAI, S.Y. (2002). Mechanisms of action of estrogen and progesterone. Ann N Y Acad Sci 955: 48-59; discussion 86-48, 396-406.

EHRLICH, C.E., YOUNG, P.C., STEHMAN, F.B., SUTTON, G.P. and ALFORD, W.M. (1988). Steroid receptors and clinical outcome in patients with adenocarcinoma of the endometrium. Am J Obstet Gynecol 158: 796-807.

ELLMANN, S., STICHT, H., THIEL, F., BECKMANN, M.W., STRICK, R. and STRISSEL, P.L. (2009). Estrogen and progesterone receptors: from molecular structures to clinical targets. Cell Mol Life Sci 66: 2405-2426.

FISCELLA, K., EISINGER, S.H., MELDRUM, S., FENG, C., FISHER, S.G. and GUZICK D.S. (2006). Effect of mifepristone for symptomatic leiomyomata on quality of life and uterine size: a randomized controlled trial. Obstet Gynecol 108: 1381-1387.

FRANCO, H.L., DAI, D., LEE, K.Y., RUBEL, C.A., ROOP, D., BOERBOOM, D., JEONG, J.W., LYDON, J.P., BAGCHI, I.C., BAGCHI, M.K. et al., (2011). WNT4 is a key regulator of normal postnatal uterine development and progesterone signaling during embryo implantation and decidualization in the mouse. Faseb J 25: 1176-1187.

FRANCO, H.L., RUBEL, C.A., LARGE, M.J., WETENDORF, M., FERNANDEZVALDIVIA, R., JEONG, J.W., SPENCER, T.E., BEHRINGER, R.R., LYDON, J.P. and DEMAYO, F.J. (2012). Epithelial progesterone receptor exhibits pleiotropic roles in uterine development and function. Faseb $J$ 26: 1218-1227.

FUJIMOTO, J., ICHIGO, S., HORI, M., NISHIGAKI, M. and TAMAYA, T. (1995). Expression of progesterone receptor form $A$ and $B$ mRNAs in gynecologic malignant tumors. Tumour Biol 16: 254-260.

GELLERSEN, B., FERNANDES, M.S. and BROSENS, J.J. (2009). Non-genomic progesterone actions in female reproduction. Hum Reprod Update 15: 119-138.

GENDRON, R.L., PARADIS, H., HSIEH-LI, H.M., LEE, D.W., POTTER, S.S. and MARKOFF, E. (1997). Abnormal uterine stromal and glandular function associated with maternal reproductive defects in Hoxa-11 null mice. Biol Reprod 56: 1097-1105.

GIANGRANDE, P.H., KIMBREL, E.A., EDWARDS, D.P. and MCDONNELL, D.P. (2000). The opposing transcriptional activities of the two isoforms of the human progesterone receptor are due to differential cofactor binding. Mol Cell Biol 20 3102-3115.

GIANGRANDE, P.H., POLLIO, G. and MCDONNELL, D.P. (1997). Mapping and characterization of the functional domains responsible for the differential activity of the $\mathrm{A}$ and $\mathrm{B}$ isoforms of the human progesterone receptor. $\mathrm{J} \mathrm{Biol}$ Chem 272 32889-32900.

GIUDICE, L.C. and KAO, L.C. (2004). Endometriosis. Lancet 364: 1789-1799.

GRONEMEYER, H. (1991). Transcription activation by estrogen and progesterone receptors. Annu Rev Genet 25: 89-123.

GRONEMEYER, H., TURCOTTE, B., QUIRIN-STRICKER, C., BOCQUEL, M.T., MEYER, M.E., KROZOWSKI, Z., JELTSCH, J.M., LEROUGE, T., GARNIER, J.M. and CHAMBON, P. (1987). The chicken progesterone receptor: sequence, expression and functional analysis. Embo J 6: 3985-3994.

GUIOCHON-MANTEL, A., LOOSFELT, H., LESCOP, P., SAR, S., ATGER, M., PERROT-APPLANAT, M. and MILGROM, E. (1989). Mechanisms of nuclear localization of the progesterone receptor: evidence for interaction between monomers. Cell 57: 1147-1154.

GUNDERSON, C.C., FADER, A.N., CARSON, K.A. and BRISTOW, R.E. (2012). Oncologic and reproductive outcomes with progestin therapy in women with endometrial hyperplasia and grade 1 adenocarcinoma: a systematic review. Gynecol Oncol 125: 477-482.

HAM, J., THOMSON, A., NEEDHAM, M., WEBB, P. and PARKER, M. (1988). Characterization of response elements for androgens, glucocorticoids and progestins in mouse mammary tumour virus. Nucleic Acids Res 16: 5263-5276.

HANNA, R., PANG, Y., THOMAS, P. and ZHU, Y. (2006). Cell-surface expression, progestin binding, and rapid nongenomic signaling of zebrafish membrane progestin receptors alpha and beta in transfected cells. J Endocrinol 190: 247-260.

HERRMANN, W., WYSS, R., RIONDEL, A., PHILIBERT, D., TEUTSCH, G., SAKIZ E. and BAULIEU, E.E. (1982). [The effects of an antiprogesterone steroid in women: interruption of the menstrual cycle and of early pregnancy]. $C R$ Seances Acad Sci III 294: 933-938.

HOEKSTRA, A.V., SEFTON, E.C., BERRY, E., LU, Z., HARDT, J., MARSH, E., YIN P., CLARDY, J., CHAKRAVARTI, D., BULUN, S. et al., (2009). Progestins activate the AKT pathway in leiomyoma cells and promote survival. J Clin Endocrinol Metab 94: 1768-1774

HSUEH, A.J., PECK, E.J., JR. and CLARK, J.H. (1975). Progesterone antagonism of the oestrogen receptor and oestrogen-induced uterine growth. Nature254:337-339.

ISHIKAWA, H., ISHI, K., SERNA, V.A., KAKAZU, R., BULUN, S.E. and KURITA, T. (2010). Progesterone is essential for maintenance and growth of uterine leiomyoma Endocrinology 151: 2433-2442.

KAKU, T., YOSHIKAWA, H., TSUDA, H., SAKAMOTO, A., FUKUNAGA, M., KUWABARA, Y., HATAEG, M., KODAMA, S., KUZUYA, K., SATO, S. et al., (2001) Conservative therapy for adenocarcinoma and atypical endometrial hyperplasia of the endometrium in young women: central pathologic review and treatment outcome. Cancer Lett 167: 39-48.

KARTERIS, E., ZERVOU, S., PANG, Y., DONG, J., HILLHOUSE, E.W., RANDEVA, H.S and THOMAS, P. (2006). Progesterone signaling in human myometrium through two novel membrane $G$ protein-coupled receptors: potential role in functional progesterone withdrawal at term. Mol Endocrinol 20: 1519-1534

KASTNER, P., KRUST, A., TURCOTTE, B., STROPP, U., TORA, L., GRONEMEYER, $\mathrm{H}$. and CHAMBON, P. (1990). Two distinct estrogen-regulated promoters generate transcripts encoding the two functionally different human progesterone receptor forms A and B. Embo J 9: 1603-1614.

KETTEL, L.M., MURPHY, A.A., MORALES, A.J., ULMANN, A., BAULIEU, E.E. and YEN, S.S. (1996). Treatment of endometriosis with the antiprogesterone mifepristone (RU486). Fertil Steril 65: 23-28.

KIM, J.J., KURITA, T. and BULUN, S.E. (2013). Progesterone action in endometrial cancer, endometriosis, uterine fibroids, and breast cancer. EndocrRev34:130-162.

KUMAR, N.S., RICHER, J., OWEN, G., LITMAN, E., HORWITZ, K.B. and LESLIE K.K. (1998). Selective down-regulation of progesterone receptor isoform $B$ in poorly differentiated human endometrial cancer cells: implications for unopposed estrogen action. Cancer Res 58: 1860-1865.

KUMAR, V. and CHAMBON, P. (1988). The estrogen receptor binds tightly to its responsive element as a ligand-induced homodimer. Cell 55: 145-156.

KURIHARA, I., LEE, D.K., PETIT, F.G., JEONG, J., LEE, K., LYDON, J.P., DEMAYO, F.J., TSAI, M.J. and TSAI, S.Y. (2007). COUP-TFII mediates progesterone 
regulation of uterine implantation by controlling ER activity. PLOS Genet 3: e102.

LAMMINEN, S., RANTALA, I., HELIN, H., RORARIUS, M. and TUIMALA, R. (1992). Proliferative activity of human uterine leiomyoma cells as measured by automatic image analysis. Gynecol Obstet Invest 34: 111-114.

LEE, K., JEONG, J., KWAK, I., YU, C.T., LANSKE, B., SOEGIARTO, D.W., TOFTGARD, R., TSAI, M.J., TSAI, S., LYDON, J.P. et al., (2006). Indian hedgehog is a major mediator of progesterone signaling in the mouse uterus. Nat Genet38: 1204-1209.

LEE, K.Y., JEONG, J.W., WANG, J., MA, L., MARTIN, J.F., TSAI, S.Y., LYDON, J.P. and DEMAYO, F.J. (2007). Bmp2 is critical for the murine uterine decidual response. Mol Cell Biol 27: 5468-5478.

LI, Q., KANNAN, A., DEMAYO, F.J., LYDON, J.P., COOKE, P.S., YAMAGISHI, H., SRIVASTAVA, D., BAGCHI, M.K. and BAGCHI, I.C. (2011). The antiproliferative action of progesterone in uterine epithelium is mediated by Hand2. Science 331: 912-916.

LIM, H., MA, L., MA, W.G., MAAS, R.L. and DEY, S.K. (1999). Hoxa-10 regulates uterine stromal cell responsiveness to progesterone during implantation and decidualization in the mouse. Mol Endocrinol 13: 1005-1017.

LYDON, J.P., DEMAYO, F.J., FUNK, C.R., MANI, S.K., HUGHES, A.R., MONTGOMERY, C.A., JR., SHYAMALA, G., CONNEELY, O.M. and O'MALLEY, B.W. (1995). Mice lacking progesterone receptor exhibit pleiotropic reproductive abnormalities. Genes Dev 9: 2266-2278.

MANI, S.K., ALLEN, J.M., LYDON, J.P., MULAC-JERICEVIC, B., BLAUSTEIN, J.D., DEMAYO, F.J., CONNEELY, O. and O'MALLEY, B.W. (1996). Dopamine requires the unoccupied progesterone receptor to induce sexual behavior in mice. Mol Endocrinol 10: 1728-1737.

MCKENNA, N.J. and O'MALLEY, B.W. (2002). Combinatorial control of gene expression by nuclear receptors and coregulators. Cell 108: 465-474.

MEYER, M.E., PORNON, A., Jl, J.W., BOCQUEL, M.T., CHAMBON, P. and GRONEMEYER, H. (1990). Agonistic and antagonistic activities of RU486 on the functions of the human progesterone receptor. Embo J 9: 3923-3932.

MOTE, P.A., BALLEINE, R.L., MCGOWAN, E.M. and CLARKE, C.L. (1999). Colocalization of progesterone receptors $A$ and $B$ by dual immunofluorescent histochemistry in human endometrium during the menstrual cycle. J Clin Endocrinol Metab 84: 2963-2971.

MUKHERJEE, A., SOYAL, S.M., FERNANDEZ-VALDIVIA, R., GEHIN, M., CHAMBON, P., DEMAYO, F.J., LYDON, J.P. and O'MALLEY, B.W. (2006). Steroid receptor coactivator 2 is critical for progesterone-dependent uterine function and mammary morphogenesis in the mouse. Mol Cell Biol 26: 6571-6583.

MULAC-JERICEVIC, B. and CONNEELY, O.M. (2004). Reproductive tissue selective actions of progesterone receptors. Reproduction 128: 139-146.

MULAC-JERICEVIC, B., LYDON, J.P., DEMAYO, F.J. and CONNEELY, O.M. (2003). Defective mammary gland morphogenesis in mice lacking the progesterone receptor B isoform. Proc Natl Acad Sci USA 100: 9744-9749.

MULAC-JERICEVIC, B., MULLINAX, R.A., DEMAYO, F.J., LYDON, J.P. and CONNEELY, O.M. (2000). Subgroup of reproductive functions of progesterone mediated by progesterone receptor-B isoform. Science 289: 1751-1754.

OLIVE, D.L. and PRITTS, E.A. (2001). Treatment of endometriosis. N Engl J Med 345: 266-275

PARKER, W.H. (2007). Etiology, symptomatology, and diagnosis of uterine myomas. Fertil Steril 87: 725-736.

PEREIRA, F.A., QIU, Y., ZHOU, G., TSAI, M.J. and TSAI, S.Y. (1999). The orphan nuclear receptor COUP-TFIl is required for angiogenesis and heart development. Genes Dev 13: 1037-1049.

PRATT, W.B. and TOFT, D.O. (1997). Steroid receptor interactions with heat shock protein and immunophilin chaperones. Endocr Rev 18: 306-360.

RAMIREZ, P.T., FRUMOVITZ, M., BODURKA, D.C., SUN, C.C. and LEVENBACK, C. (2004). Hormonal therapy for the management of grade 1 endometrial adenocarcinoma: a literature review. Gynecol Oncol 95: 133-138.

RAMONDETTA, L.M., JOHNSON, A.J., SUN, C.C., ATKINSON, N., SMITH, J.A., JUNG, M.S., BROADDUS, R., IYER, R.B. and BURKE, T. (2009). Phase 2 trial of mifepristone (RU-486) in advanced or recurrent endometrioid adenocarcinoma or low-grade endometrial stromal sarcoma. Cancer 115: 1867-1874.

RUBEL, C.A., LANZ, R.B., KOMMAGANI, R., FRANCO, H.L., LYDON, J.P. and DEMAYO, F.J. (2012). Research resource: Genome-wide profiling of progesterone receptor binding in the mouse uterus. Mol Endocrinol 26: 1428-1442.
SAITO, S., ITO, K., NAGASE, S., SUZUKI, T., AKAHIRA, J., OKAMURA, K., YAEGASHI, $\mathrm{N}$. and SASANO, $\mathrm{H}$. (2006). Progesterone receptor isoforms as a prognostic marker in human endometrial carcinoma. Cancer Sci 97: 1308-1314.

SAKAGUCHI, H., FUJIMOTO, J., HONG, B.L., NAKAGAWA, Y. and TAMAYA, T. (2004). Drastic decrease of progesterone receptor form $B$ but not A mRNA reflects poor patient prognosis in endometrial cancers. Gynecol Oncol 93: 394-399.

SAMALECOS, A. and GELLERSEN, B. (2008). Systematic expression analysis and antibody screening do not support the existence of naturally occurring progesterone receptor (PR)-C, PR-M, or other truncated PR isoforms. Endocrinology 149: 5872-5887.

SARTORIUS, C.A., MELVILLE, M.Y., HOVLAND, A.R., TUNG, L., TAKIMOTO, G.S. and HORWITZ, K.B. (1994). A third transactivation function (AF3) of human progesterone receptors located in the unique $\mathrm{N}$-terminal segment of the $\mathrm{B}$-isoform. Mol Endocrinol 8: 1347-1360.

SHERMAN, M.E. (2000). Theories of endometrial carcinogenesis: a multidisciplinary approach. Mod Pathol 13: 295-308.

SIEGEL, R., WARD, E., BRAWLEY, O. and JEMAL, A. (2011). Cancer statistics, 2011: the impact of eliminating socioeconomic and racial disparities on premature cancer deaths. CA Cancer J Clin 61: 212-236.

SITRUK-WARE, R. (2004). Pharmacological profile of progestins. Maturitas 47: 277-283.

SMITH, C.L. and O'MALLEY, B.W. (2004). Coregulator function: a key to understanding tissue specificity of selective receptor modulators. Endocr Rev 25: 45-71.

SMITH, J.L., KUPCHAK, B.R., GARITAONANDIA, I., HOANG, L.K., MAINA, A.S., REGALLA, L.M. and LYONS, T.J. (2008). Heterologous expression of human $\mathrm{mPRalpha}$, mPRbeta and mPRgamma in yeast confirms their ability to function as membrane progesterone receptors. Steroids 73: 1160-1173.

SMITH, W.L., GARAVITO, R.M. and DEWITT, D.L. (1996). Prostaglandin endoperoxide $\mathrm{H}$ synthases (cyclooxygenases)-1 and -2. J Biol Chem 271: 33157-33160.

SOYAL, S.M., MUKHERJEE, A., LEE, K.Y., LI, J., LI, H., DEMAYO, F.J. and LYDON, J.P. (2005). Cre-mediated recombination in cell lineages that express the progesterone receptor. Genesis 41: 58-66.

SPITZ, I.M. (2003). Progesterone antagonists and progesterone receptor modulators: an overview. Steroids 68: 981-993.

SPITZ, I.M. (2009). Clinical utility of progesterone receptor modulators and their effect on the endometrium. Curr Opin Obstet Gynecol 21: 318-324.

STEPHEN, E.H. and CHANDRA, A. (2000). Use of infertility services in the United States: 1995. Fam Plann Perspect 32: 132-137.

SUN, H.S., HSIAO, K.Y., HSU, C.C., WU, M.H. and TSAI, S.J. (2003). Transactivation of steroidogenic acute regulatory protein in human endometriotic stromalcells is mediated by the prostaglandin EP2 receptor. Endocrinology 144: 3934-3942.

TAKAMOTO, N., KURIHARA, I., LEE, K., DEMAYO, F.J., TSAI, M.J. and TSAI, S.Y. (2005). Haploinsufficiency of chicken ovalbumin upstream promoter transcription factor II in female reproduction. Mol Endocrinol 19: 2299-2308.

TAYLOR, H.S., ARICI, A., OLIVE, D. and IGARASHI, P. (1998). HOXA10 is expressed in response to sex steroids at the time of implantation in the human endometrium. $J$ Clin Invest 101: 1379-1384.

TAYLOR, H.S., IGARASHI, P., OLIVE, D.L. and ARICI, A. (1999). Sex steroids mediate HOXA11 expression in the human peri-implantation endometrium. $J$ Clin Endocrinol Metab 84: 1129-1135.

THIGPEN, J.T., BRADY, M.F., ALVAREZ, R.D., ADELSON, M.D., HOMESLEY, H.D., MANETTA, A., SOPER, J.T. and GIVEN, F.T. (1999). Oral medroxyprogesterone acetate in the treatment of advanced or recurrent endometrial carcinoma: a doseresponse study by the Gynecologic Oncology Group. J Clin Oncol 17: 1736-1744.

TRANGUCH, S., CHEUNG-FLYNN, J., DAIKOKU, T., PRAPAPANICH, V., COX, M.B. XIE, H., WANG, H., DAS, S.K., SMITH, D.F. and DEY, S.K. (2005). Cochaperone immunophilin FKBP52 is critical to uterine receptivity for embryo implantation. Proc Natl Acad Sci USA 102: 14326-14331.

TRANGUCH, S., WANG, H., DAIKOKU, T., XIE, H., SMITH, D.F. and DEY, S.K. (2007). FKBP52 deficiency-conferred uterine progesterone resistance is genetic background and pregnancy stage specific. J Clin Invest 117: 1824-1834.

USHIJIMA, K., YAHATA, H., YOSHIKAWA, H., KONISHI, I., YASUGI, T., SAITO, T., NAKANISHI, T., SASAKI, H., SAJI, F., IWASAKA, T. et al., (2007). Multicenter phase II study of fertility-sparing treatment with medroxyprogesterone acetate for endometrial carcinoma and atypical hyperplasia in young women. $J$ Clin Oncol 25: 2798-2803. 
VEGETO, E., SHAHBAZ, M.M., WEN, D.X., GOLDMAN, M.E., O'MALLEY, B.W. and MCDONNELL, D.P. (1993). Human progesterone receptor A form is a cell- and promoter-specific repressor of human progesterone receptor $\mathrm{B}$ function. $\mathrm{Mol}$ Endocrinol 7: 1244-1255.

VERCELLINI, P., CORTESI, I. and CROSIGNANI, P.G. (1997). Progestins for symptomatic endometriosis: a critical analysis of the evidence. Fertil Steril68: 393-401.

VICENT, G.P., NACHT, A.S., ZAURIN, R., FONT-MATEU, J., SORONELLAS, D., LE DILY, F., REYES, D. and BEATO, M. (2013). Unliganded progesterone receptormediated targeting of an RNA-containing repressive complex silences a subset of hormone-inducible genes. Genes Dev 27: 1179-1197.

WANG, H. and DEY, S.K. (2006). Roadmap to embryo implantation: clues from mouse models. Nat Rev Genet 7: 185-199.

WEI, L.L., HAWKINS, P., BAKER, C., NORRIS, B., SHERIDAN, P.L. and QUINN, P.G. (1996). An amino-terminal truncated progesterone receptor isoform, PRc, enhances progestin-induced transcriptional activity. Mol Endocrinol10: 1379-1387.

WEI, L.L. and MINER, R. (1994). Evidence for the existence of a third progesterone receptor protein in human breast cancer cell line T47D. Cancer Res 54: 340-343.

WEI, L.L., NORRIS, B.M. and BAKER, C.J. (1997). An N-terminally truncated third progesterone receptor protein, $\mathrm{PR}(\mathrm{C})$, forms heterodimers with $\mathrm{PR}(\mathrm{B})$ but interferes in PR(B)-DNA binding. J Steroid Biochem Mol Biol 62: 287-297.

WHITNEY, C.W., BRUNETTO, V.L., ZAINO, R.J., LENTZ, S.S., SOROSKY, J., ARMSTRONG, D.K. and LEE, R.B. (2004). Phase II study of medroxyprogesterone acetate plus tamoxifen in advanced endometrial carcinoma: a Gynecologic Oncology Group study. Gynecol Oncol 92: 4-9.
WILCOX, L.S., KOONIN, L.M., POKRAS, R., STRAUSS, L.T., XIA, Z. and PETERSON, H.B. (1994). Hysterectomy in the United States, 1988-1990. Obstet Gynecol 83: 549-555.

XU, J., QIU, Y., DEMAYO, F.J., TSAI, S.Y., TSAI, M.J. and O'MALLEY, B.W. (1998). Partial hormone resistance in mice with disruption of the steroid receptor coactivator-1 (SRC-1) gene. Science 279: 1922-1925.

YAMADA, T., NAKAGO, S., KURACHI, O., WANG, J., TAKEKIDA, S., MATSUO, H and MARUO, T. (2004). Progesterone down-regulates insulin-like growth factorexpression in cultured human uterine leiomyoma cells. Hum Reprod 19: 815-821.

ZHANG, Y., BECK, C.A., POLETTI, A., CLEMENT, J.P.T., PRENDERGAST, P., YIP, T.T., HUTCHENS, T.W., EDWARDS, D.P. and WEIGEL, N.L. (1997). Phosphorylation of human progesterone receptor by cyclin-dependent kinase 2 on three sites that are authentic basal phosphorylation sites in vivo. Mol Endocrinol 11: 823-832.

ZHANG, Y., BECK, C.A., POLETTI, A., EDWARDS, D.P. and WEIGEL, N.L. (1994) Identification of phosphorylation sites unique to the $B$ form of human progesterone receptor. In vitro phosphorylation by casein kinase II. JBiol Chem269:31034-31040.

ZHANG, Y., BECK, C.A., POLETTI, A., EDWARDS, D.P. and WEIGEL, N.L. (1995). Identification of a group of Ser-Pro motif hormone-inducible phosphorylation sites in the human progesterone receptor. Mol Endocrinol 9: 1029-1040.

ZHU, Y., BOND, J. and THOMAS, P. (2003a). Identification, classification, and partial characterization of genes in humans and other vertebrates homologous to a fish membrane progestin receptor. Proc Natl Acad Sci USA 100: 2237-2242.

ZHU, Y., RICE, C.D., PANG, Y., PACE, M. and THOMAS, P. (2003b). Cloning, expression, and characterization of a membrane progestin receptor and evidence it is an intermediary in meiotic maturation of fish oocytes. Proc Natl Acad Sci USA 100: 2231-2236. 


\section{Further Related Reading, published previously in the Int. J. Dev. Biol.}

Implantation: molecular basis of embryo-uterine dialogue

B C Paria, H Song and S K Dey

Int. J. Dev. Biol. (2001) 45: 597-605

http://dx.doi.org/10.1387/ijdb.11417904

Endometrial responses to embryonic signals in the primate

Prajna Banerjee and Asgerally T. Fazleabas

Int. J. Dev. Biol. (2010) 54: 295-302

http://dx.doi.org/10.1387/ijdb.082829pb

Local regulation of implantation at the human fetal-maternal interface

Evdokia Dimitriadis, Guiying Nie, Natalie J. Hannan, Premila Paiva and Lois A. Salamonsen Int. J. Dev. Biol. (2010) 54: 313-322

http://dx.doi.org/10.1387/ijdb.082772ed

Critical growth factors and signalling pathways controlling human trophoblast invasion Martin Knöfler

Int. J. Dev. Biol. (2010) 54: 269-280

http://dx.doi.org/10.1387/ijdb.082769mk

On the role of placental major histocompatibility complex and decidual leukocytes in implantation and pregnancy success using non-human primate models

Thaddeus G. Golos, Gennadiy I. Bondarenko, Svetlana V. Dambaeva, Edith E. Breburda, and Maureen Durning

Int. J. Dev. Biol. (2010) 54: 431-443

http://dx.doi.org/10.1387/ijdb.082797tg

5 yr ISI Impact Factor $(2011)=2.959$
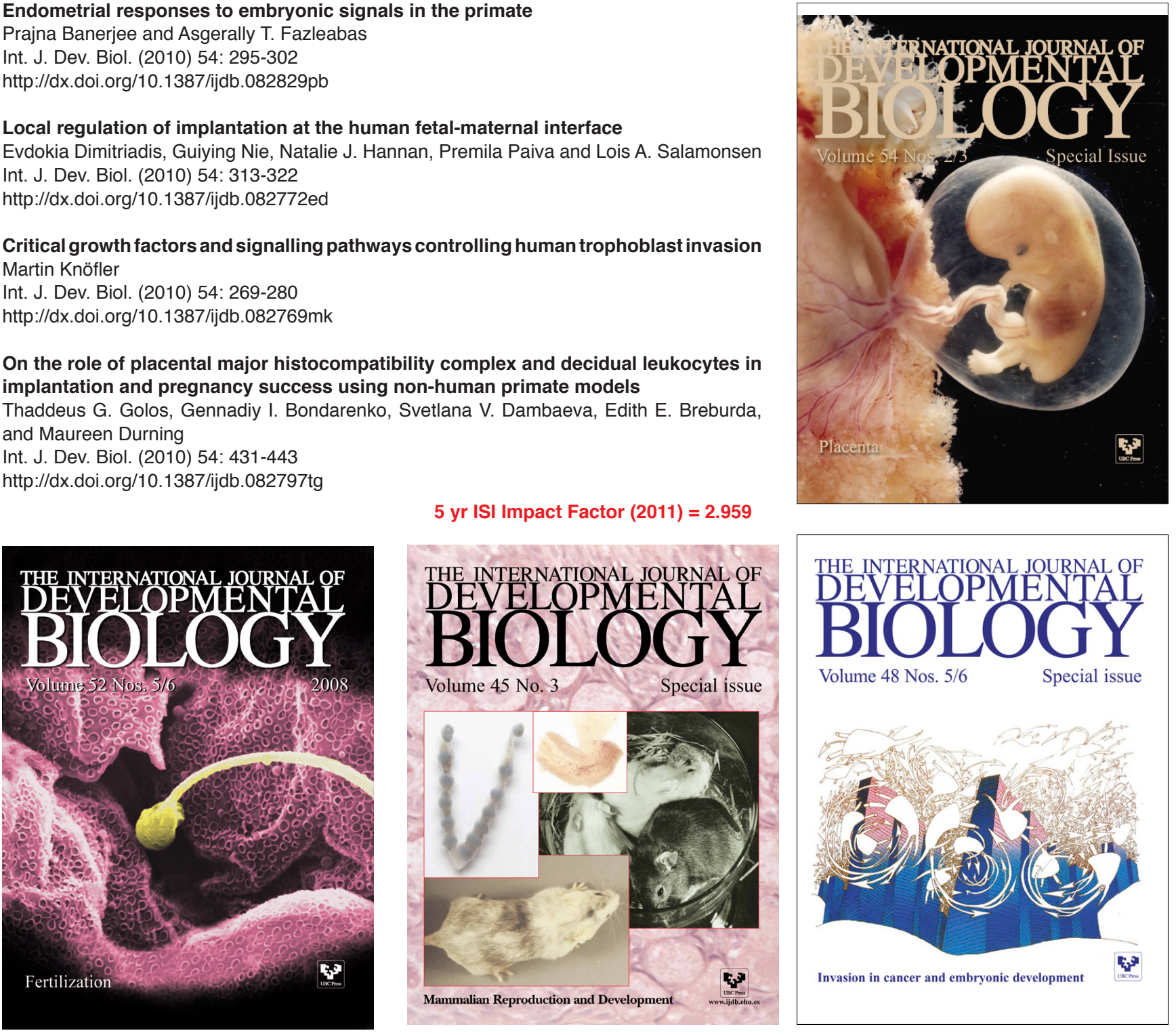

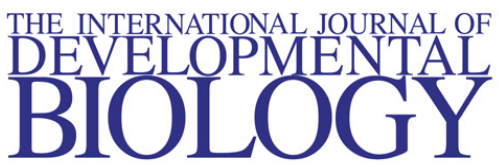

Volume 48 Nos. 5/6

Special issue

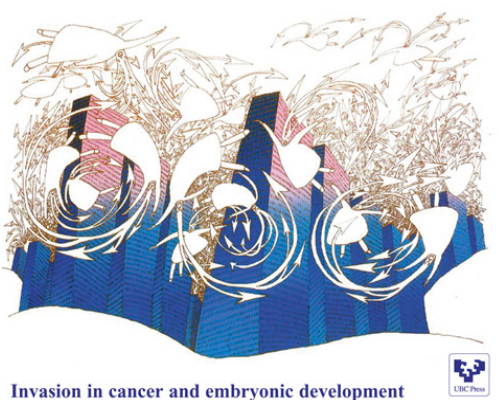

